\title{
Accumulated organic matter, litterfall production, and decomposition tell us the status of litter dynamics in forests
}

\author{
Jae Geun Kim* \\ Department of Biology Education, Seoul National University, Seoul 151-748, Korea
}

\begin{abstract}
Litterfall dynamics in forests are assessed by estimating biomass production and decomposition. However, there have been few studies on how litter dynamics impact the health and management of ecosystems. Here, a new approach to measure and assess ecosystem function is presented based on conventional methods using littertraps, litterbags, and the mass on the forest floor. To assess the status of litter dynamics, the decay rate (k) was estimated from a litterbag experiment, and removal rates $\left(\mathrm{k}_{\mathrm{i}}\right)$ were determined from mass balance on the forest floor at 21 sites on three mountains in South Korea. The $\mathrm{k}_{3}$ (organic mass ratio of $\mathrm{O}_{\mathrm{i}}$ and $\mathrm{O}_{\mathrm{e}}+\mathrm{O}_{\mathrm{a}}+\mathrm{A}$ horizons in November) values in an equilibrium state in South Korea were within the range of $\mathrm{k} \pm 0.174$ when considering the annual variation of litterfall production. This study also suggests that sampling sites for these types of studies should be in the middle, not at the ends, of steady slopes on the forest floor.
\end{abstract}

Key words: accumulated organic matter, assessment of litter dynamics status, decay rate, decomposition, forest floor, litterfall, Olson's model, removal rate

\section{INTRODUCTION}

Nutrient input and output in ecosystems is important for nutrient cycling. The rate of litterfall and decomposition as an important pathway for the transfer of litter mass and minerals to the soil surface in forest ecosystem has been quantified by many researchers (Gosz et al. 1973, Birk and Simpson 1980, Hobbie et al. 2006). Litterfall is dominant among the aboveground components of nutrient input (Kim and Chang 1989, Shin et al. 2011), and litter production in forest ecosystems varies with community structure and nutrient conditions. Temperature, precipitation, soil, light, and other environmental factors can also have an impact (Barbour et al. 1999). Litterfall generally increases during succession and has been shown to peak at various times depending upon the region and forest type: 14 years in eastern Guatemala (Ewel 1976), 46 years in Alnus plantation in the eastern Himalaya (Shar- ma and Ambasht 1987), and the period of crown closure in Douglas-fir stands as the time of maximum wood productivity (Turner and Long 1975).

Forest litter decomposition rates are known to be influenced by macro- and microclimate variables (Edwards 1975, Insam 1990), as well as by the chemical composition of the litter (Meentemeyer 1978, Melillo et al. 1982, Gallardo and Merino 1993, Rustad 1994, Laskowski et al. 1995, Hobbie et al. 2006). On a global scale, rates of litter decomposition are regulated by climate (Johansson et al. 1995). However, within a particular climatic region, litter chemistry was known to be the best indicator of decomposition rates (Taylor et al. 1991, Aerts 1996). Litter lignin content is negatively related to mass loss and is positively correlated to the calcium content (Hobbie et al. 2006). Soil microbes biologically decompose most lit-

\section{Open Access http://dx.doi.org/10.5141/JEFB.2012.014}

This is an Open Access article distributed under the terms of the Creative Commons Attribution Non-Commercial License (http://creativecommons. org/licenses/by-nc/3.0/) which permits unrestricted non-commercial use distribution, and reproduction in any medium, provided the original work is properly cited.
Received 20 February 2012, Accepted 29 March 2012

*Corresponding Author

E-mail: jaegkim@snu.ac.kr

Tel: +82-2-880-7896 
ter and microclimate or microenvironmental conditions are also important factors for decomposition (Yavitt and Fahey 1986).

Decomposition rates are also related with succession. This rate was found to peak at 30 years in an Alnus plantation in the eastern Himalayas (Sharma and Ambasht 1987) and in a 24-year-old stand of Douglas firs, where temperature and moisture conditions were most favorable (Edmonds 1979). However, Ewel (1976) reported that loss of dry weight occurs at a generally consistent rate regardless of the age of the forest.

In a forest, litter production and decomposition are responsible for the formation of the forest floor; this formation is a long-term process that is indicative of the nutrient cycling rate (Johansson et al. 1995). Litter accumulates on the soil surface until litterfall equals litter decomposition; after which, the amount of litter accumulated on the soil surface oscillates around some mean steady-state value (Ewel 1976). Litter decomposition rates and forest floor characteristics yield information about the quality of litter as well as the rates of nutrient cycling within an ecosystem (Knoepp et al. 2000).

Ecosystem functional processes (e.g., productivity and decomposition) are generally known as important indicators of ecosystem stability or homeostasis (van Voris et al. 1980, Odum 1985, Rapport et al. 1985). Decomposition is a function of an ecosystem that includes a robust food chain supporting the desired biota, an adequate nutrient pool for desired organisms, and adequate nutrient cycling to perpetuate the ecosystem (Schaeffer et al. 1988). It is an important indicator of ecosystem stability involving the interaction of vegetation, soil nutrient availability, micro- and macro-fauna, and microbial populations (Knoepp et al. 2000). If decomposition is impaired, the ecosystem is functionally impaired (Schaeffer et al. 1988). Decomposition rates can provide an accurate prediction of soil and site quality or productivity (Johansson 1994). Increasing rates of litter decomposition accelerate nutrient cycling rates within the site and indicates increased soil quality (Johansson et al. 1995). However, it is not easy to assess the status of nutrient dynamics based on production and decomposition without long-term monitoring. Gessner and Chauvet (2002) suggested a method for evaluating ecosystem health using a decomposition rate $\mathrm{k}$ (impacted)/k (reference) ratio in stream ecosystems. In the present study, another complementary approach for assessing ecological integrity of forest ecosystems is proposed, which compares decomposition rates calculated by litterbag methods and the mass balance on the forest floor along with real and the theoretical mass remains.
In general, littertraps and litterbags are used to measure litter input and output on the forest floor. However, these methods have inherent problems, including large variation in litterfall from year to year, difficulties in accounting for very small litter fragments, short experimental periods, and the accessibility of the litterbag to organism (Knutson 1997). To avoid these problems, Knutson (1997) estimated annual production and decomposition of litter by examining unconfined litter using the disappearance from a litter layer as a measure of decomposition. However, it is still not easy to examine all unconfined litter, and many studies have used the litter amount in each litter layer (e.g., $\mathrm{O}_{\mathrm{i}}, \mathrm{O}_{\mathrm{e}}, \mathrm{O}_{\mathrm{a}}$, and A horizon based on Brady and Weil 2008) to estimate decomposition rates in deciduous forests with the assumption that there was a steady state of litter input and output (Chang and Ko 1982, Chang and Kim 1983, Chang et al. 1987, Hobbie et al. 2006). However, decomposition rates estimated by the litterbag method and mass balance on the forest floor are based on different assumptions that do not often correlate.

For the litterbag method, decomposition rates can be estimated by an exponential decay model, with $\mathrm{k}$ being the parameter from the exponential equation:

$$
\mathrm{X}_{\mathrm{t}}=\mathrm{X}_{0} \mathrm{e}^{-\mathrm{kt}} \text {, }
$$

where $\mathrm{X}_{0}$ is the initial \% weight; e the nature log constant; and $\mathrm{k}(1 / \mathrm{y})$ the decomposition constant (Olson 1963, Swift et al. 1979). This can be converted to:

$$
\mathrm{k}=-1 / \mathrm{t} \ln \left(\mathrm{X}_{\mathrm{t}} / \mathrm{X}_{0}\right) \text {. }
$$

In the forest floor, the decomposition rate can be estimated by mass balance assuming there is a steady state as follows (Olson 1963, Hobbie et al. 2006):

$$
\mathrm{k}_{\mathrm{i}}=\mathrm{L} / \mathrm{F} \text {, }
$$

where $\mathrm{L}$ is the annual literfall organic mass, and $\mathrm{F}$ is the forest floor organic mass $\mathrm{O}_{\mathrm{i}}+\mathrm{O}_{\mathrm{e}}+\mathrm{O}_{\mathrm{a}}+$ A horizon organic mass). If litter dynamics in a forest floor are in a steady state, the $k$ value should be the same or similar to the $k_{i}$ value. If the litterfall input on the forest floor is larger than the output, $\mathrm{k}_{\mathrm{i}}$ should be less than $\mathrm{k}$.

Organic accumulation (OAcc) with continuous litterfall can be expressed by the equation:

$$
\text { OAcc }=(L / k)\left(1-\mathrm{e}^{-k t}\right),
$$

in which the value of $\left(1-\mathrm{e}^{-\mathrm{kt}}\right)$ is close to 1 when $\mathrm{k}$ is larger than 0.25 and $t$ is longer than 30 years, and OAcc $\cong \mathrm{L} / \mathrm{k}$. This OAcc is the theoretical organic accumulated mass on the forest floor at a steady state arrived at using current litter bag $\mathrm{k}$ values and current litterfall. This theoretical 
value can be compared to the actual organic mass on the forest floor (OMFF) to determine if current litter dynamics are faster, slower, or equal to those in recent decades over which the forest floor mass accumulated.

Here, I suggest a hypothesis: a comparison of $k$ and $k_{i}$ will indicate the status of litter dynamics in forests. If $k$ and $\mathrm{k}_{\mathrm{i}}$ or OMFF and OAcc are similar, then litter dynamics are assumed to be in equilibrium or a steady state. If the litter bag-derived $k$ values (indicative of current conditions) are smaller than $\mathrm{k}_{\mathrm{i}}$ calculated from actual forest floor data (integrated over past decades), then the OAcc estimated using current inputs and outputs will be greater than the OMFF actually measured, which means that, therefore, in the past, litter output has been relatively greater than litter input, as compared to that ratio currently. In contrast, if $\mathrm{k}>\mathrm{k}_{\mathrm{i}}$, then the estimated OAcc will be less than the actual OMFF, and in the past, litter output has been relatively less than litter input, as compared to that ratio currently. Field data from forests on three well-conserved mountains that have been a part of the national parks in South Korea for more than 30 years are also presented to demonstrate how to apply this new approach. Loss or gain of litter mass would be expected to differentially affect germination and establishment of plants, soil invertebrates and vertebrates, and the exchange of $\mathrm{CO}_{2}$ with atmosphere, the carbon cycle, etc. (Schaeffer et al. 1988, Vitousek 1994, Knoepp et al. 2000, Gessner and Chauvet 2002). This study may play an important role in predicting litter-mass trajectories (steady state, increasing, or decreasing forest floor organic matter) into the future.

\section{MATERIALS AND METHODS}

\section{Study site}

I tried to find sites in a steady-state condition, which means that anthropogenic disturbances were not detected, and in the broad spectrum of sites, I tried to provide enough variation in factors, such as slope, altitude, aspect, and dominant species, that determin forest floor mass, litterfall, and decomposition. Twenty-one sites on three mountains in the southwestern part of South Korea (Jirisan, Deokyusan, and Gyeryongsan) covering low to high altitudes and including representative forest species were selected (Table 1). Altitudes of the study sites ranged from $221 \mathrm{~m}$ a.s.l. in Gyeryongsan to 1,567 m a.s.l. in Deogyusan. Slope aspects of the study sites varied, and slopes ranged from $18-43^{\circ}$. Dominant species of trees in the sites were Carpinus laxiflora (2 sites), C. tschonoskii (2 sites),
Fraxinus mandshurica (2 sites), Quercus serrata (3 sites), Q. mongolica (3 sites), Q. variabilis (2 sites), Q. acutissima (1 site), Pinus densiflora (3 sites; Pd1, Pd2, Pd3), and Stewartia koreana (1 site). Basal areas in the study sites ranged from $16.3 \mathrm{~m}^{2} /$ ha to $50.2 \mathrm{~m}^{2} /$ ha (average, $30.9 \mathrm{~m}^{2} / \mathrm{ha}$ ). The density of trees larger than $5 \mathrm{~cm}$ diameter at breast height ranged from 494 trees/ha to 1,856 trees/ha (average, 958 trees/ha). The average basal area of the trees was largest at the Qs1 site in the Q. serrata community and smallest at the Fm2 site in the F. mandshurica community.

The climate of the region is summer monsoonal. Mean annual precipitation was $1,400 \mathrm{~mm}$ in Jirisan; $1,270 \mathrm{~mm}$ in Deogyusan; and 1,350 mm in Gyeryongsan, and more than half of the precipitation falls between May and August. The mean annual temperature was $12.5^{\circ} \mathrm{C}$ in Jirisan, $11.5^{\circ} \mathrm{C}$ in Deogyusan, and $12.3^{\circ} \mathrm{C}$ in Gyeryongsan. Soil types were silt loam or silt clay loam. Soil pH of the upper $5 \mathrm{~cm}$ ranged between 4 and 5 (Korea National Park Service 2002, 2004a, 2004b).

\section{Litterfall}

Rectangular litter traps with a $1-\mathrm{m}^{2}$ internal surface area were used to intercept litterfall. The bottom of the traps was a 1-mm mesh stainless steel screen. The traps were fixed $1 \mathrm{~m}$ above the soil surface. Two traps in Jirisan and three each in Deogyusan and Gyeryongsan were placed at each site within $50 \mathrm{~m} \times 50 \mathrm{~m}$ quadrats. Fallen litter was harvested in the 4 th week of August and November in Jirisan during 2001-2003, and the 4th week of February, 3rd week of April, and 4th week of May, July, September, and November in Deogyusan and Gyeryongsan during 20052008.

\section{Litter decomposition experiments}

Even though litter includes dead leaves, twigs, logs, fine roots, and soil microorganisms, dead leaf was the most abundant source of litter (Korea National Park Service 2002), and I used dead leaves as litter in this experiment. For each site, litter from the site for litterbags was obtained by collection of the litter on the $\mathrm{O}_{\mathrm{i}}$ horizon of the forest floor in early November. The litter was mixed and air dried. Nylon litterbags measuring $20 \mathrm{~cm} \times 20 \mathrm{~cm}$ with a mesh size of $1 \mathrm{~mm}$ were prepared. Litterbags were filled with $15 \mathrm{~g}$ of air-dried litter. The bags were anchored on the $\mathrm{O}_{\mathrm{e}}$ layer of the forest floor with heavy gauge wire and covered with litter. Litterbags were randomly sampled in four replicates at each collection time $(1,6,9,12,24$, and 36 months) at each site. Samples of the initial litter and 


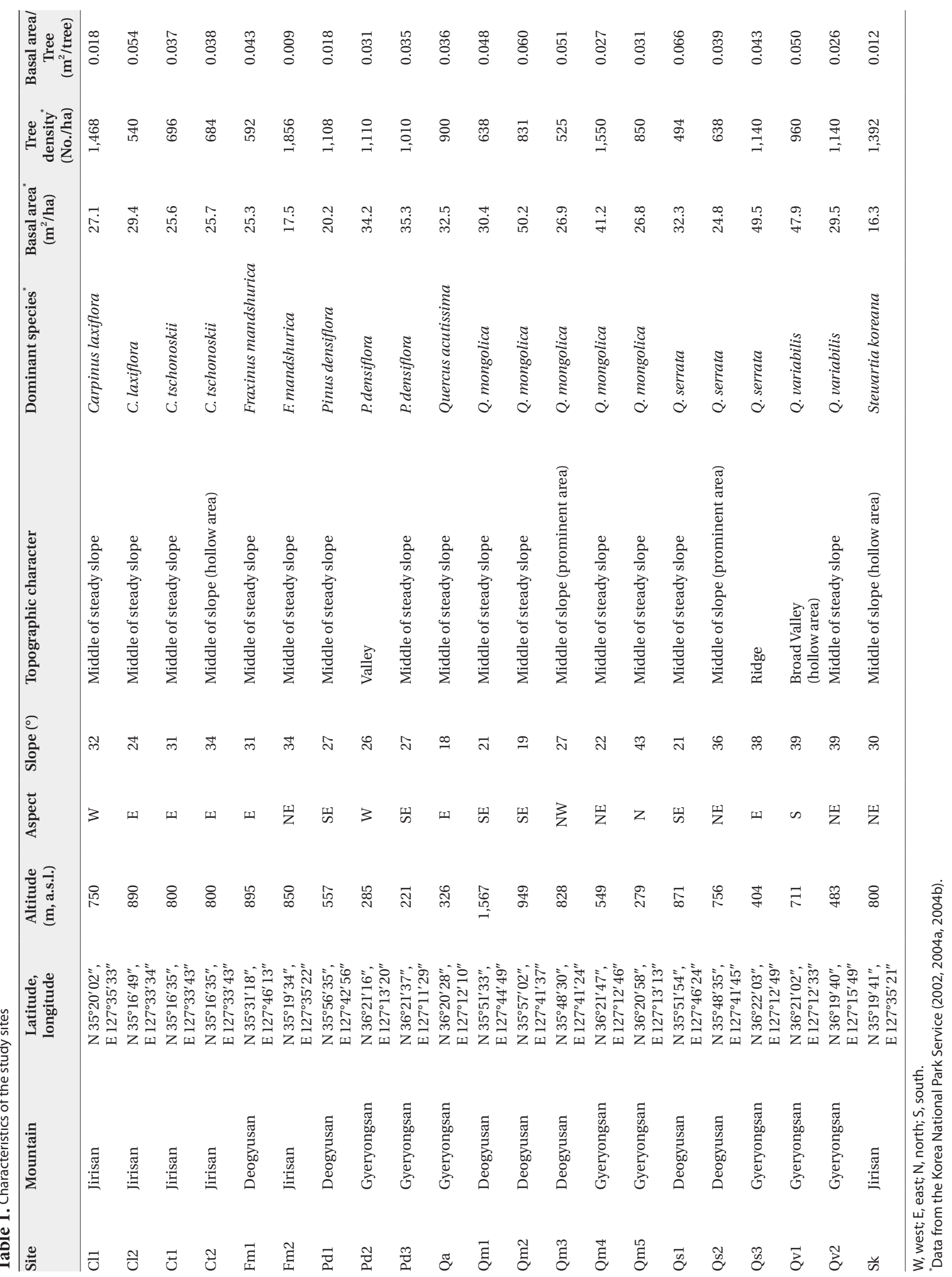


all samples recovered from each site were ground in a Wiley Mill, passed through a \#40 mesh screen, and analyzed for moisture content (dry for $24 \mathrm{~h}$ at $105^{\circ} \mathrm{C}$ ) and ash-free weight (ignition for $4 \mathrm{~h}$ at $550^{\circ} \mathrm{C}$ ).

\section{Estimation of litter removal rate by mass balance}

Litter was collected in two $20 \mathrm{~cm} \times 20 \mathrm{~cm}$ quadrats on the forest floor in each $20 \mathrm{~m} \times 20 \mathrm{~m}$ plot during the last week of November when almost all deciduous leaves have senesced in South Korea. Litter was divided into those on $\mathrm{O}_{\mathrm{i}}(\mathrm{L})$ horizon and those on $\mathrm{O}_{\mathrm{e}}(\mathrm{F}), \mathrm{O}_{\mathrm{a}}(\mathrm{H})$, and A horizons (Coleman et al. 2004, Brady and Weil 2008). The collected litter was air dried and ground in a Willey Mill to be passed through a \#40 mesh screen. Ground litter was ignited in a furnace at $550^{\circ} \mathrm{C}$ for $4 \mathrm{~h}$. The following calculations were performed with the ash-free mass.

Hobbie et al. (2006) suggested calling the estimated decomposition rate by mass balance on the forest floor $\left(\mathrm{k}_{\mathrm{i}}\right)$ the "removal rate"; therefore I call $k_{i}\left(k_{1}, k_{2}\right.$, and $\left.k_{3}\right)$ the "removal rate." The removal rate, $k_{1}$, on the forest floor was calculated assuming that there was a continuous litterfall mass (L), following Olson (1963):

$$
\mathrm{k}_{1}=\mathrm{L} / \mathrm{F} \text {, }
$$

where $\mathrm{F}$ is the forest floor mass at a steady state. Since litterfall was not fixed on the forest floor, litter mass on the forest floor was not the same as that collected in the littertrap. The ratio of annual litterfall to autumn litterfall was relatively constant in ecosystems where dominant species are the same (Table 2). Therefore, L was calculated from the organic mass on the $\mathrm{O}_{\mathrm{i}}$ horizon, and the autumn/annual litter production ratio in Table 2 can be represented with the equation:

$$
\mathrm{L}=\mathrm{O}_{\mathrm{i}} \times \text { (annual litterfall/autumn litterfall). }
$$

Since litterfall is relatively discrete in temperate forests, another removal rate $\left(k_{2}\right)$ was calculated using Olson's equation for discrete autumn litterfall (Hobbie et al. 2006):

$$
\mathrm{k}_{2}=-\ln \left(1-\mathrm{O}_{\mathrm{i}} / \mathrm{T}\right)
$$

where $\mathrm{T}$ is the maximum forest floor organic mass $(\mathrm{T}=$ $\mathrm{O}_{\mathrm{i}}+\mathrm{O}_{\mathrm{e}}+\mathrm{O}_{\mathrm{a}}+\mathrm{A}$ ). With this formula we can calculate the

\begin{tabular}{|c|c|c|c|c|c|}
\hline \multirow{2}{*}{ Site } & \multicolumn{2}{|c|}{ Annual litter production $\left(\mathrm{g} / \mathrm{m}^{2}\right)$} & \multirow{2}{*}{$\begin{array}{l}\text { Autumn litter production } \\
\qquad\left(\mathrm{g} / \mathrm{m}^{2}\right)\end{array}$} & \multirow{2}{*}{$\begin{array}{c}\text { Autumn/Annual litter } \\
\text { production }\end{array}$} & \multirow{2}{*}{$\begin{array}{l}\text { Concentration of ash-free } \\
\text { matter in autumn litter (\%) }\end{array}$} \\
\hline & Average & SD & & & \\
\hline $\mathrm{Cl} 1$ & 373.7 & 114.4 & 357.5 & 0.96 & 95.0 \\
\hline $\mathrm{Cl} 2$ & 443.6 & 118.4 & 366.8 & 0.83 & 92.3 \\
\hline Ct1 & 316.4 & 137.9 & 260.1 & 0.82 & 94.5 \\
\hline Ct2 & 383.1 & 60.3 & 376.8 & 0.98 & 85.7 \\
\hline Fm1 & 416.9 & 42.5 & 316.9 & 0.76 & 94.1 \\
\hline Fm2 & 281.5 & 54.3 & 260.8 & 0.93 & 94.7 \\
\hline Pd 1 & 538.4 & 61.5 & 211.6 & 0.39 & 96.1 \\
\hline $\operatorname{Pd} 2$ & 538.7 & 46.4 & 262.1 & 0.49 & 96.8 \\
\hline $\mathrm{Pd} 3$ & 637.1 & 70.4 & 249.3 & 0.39 & 94.4 \\
\hline Qa & 497.2 & 15.7 & 312.4 & 0.63 & 95.1 \\
\hline Qm1 & 323.4 & 34.8 & 204.2 & 0.63 & 93.7 \\
\hline Qm2 & 475.5 & 134.4 & 312.9 & 0.66 & 93.7 \\
\hline Qm3 & 428.9 & 30.9 & 299.6 & 0.70 & 93.8 \\
\hline Qm4 & 398.2 & 91.9 & 237.9 & 0.60 & 95.2 \\
\hline Qm5 & 427.0 & 103.1 & 270.9 & 0.63 & 95.8 \\
\hline Qs1 & 447.1 & 54.6 & 315.8 & 0.71 & 93.7 \\
\hline Qs2 & 488.8 & 75.0 & 322.2 & 0.66 & 91.9 \\
\hline Qs3 & 474.7 & 181.2 & 296.1 & 0.62 & 95.4 \\
\hline Qv1 & 508.8 & 121.3 & 369.7 & 0.73 & 80.8 \\
\hline Qv2 & 453.5 & 58.7 & 322.3 & 0.71 & 94.4 \\
\hline Sk & 258.6 & 135.0 & 239.4 & 0.93 & 94.7 \\
\hline
\end{tabular}
proportion of organic matter in the upper layer as com-

Table 2. Average annual and autumn litter production over 3 y (2001-2003) in the Jirisan sites and over 4 y (2005-2008) in Deogyusan and Gyeryongsan sites 
pared to that in all layers and that minus 1 to get the value of the mass lost. For the comparison with other removal rate data from South Korea, $\mathrm{k}_{3}$ was calculated using the equation:

$$
\mathrm{k}_{3}=\mathrm{O}_{\mathrm{i}} /\left(\mathrm{O}_{\mathrm{e}}+\mathrm{O}_{\mathrm{a}}+\mathrm{A}\right),
$$

which is an adaptation of Olson's exponential decomposition equation (Kim and Chang 1966, Chang and Kim 1983, Chang et al. 1987). If $\mathrm{O}_{\mathrm{i}}$ mass of recently fallen litter is greater than the organic mass in all the other layers below it, then $\mathrm{k}$ is fast (perhaps even greater than 1 per year). If $\mathrm{O}_{\mathrm{i}}$ is less than the accumulated mass in all the other layers below it, then $\mathrm{k}$ is slower than in the example above.

\section{Analysis}

All data on mass loss were converted to ash-free mass because we could not remove all soil particles from the decomposed litter and forest floor mass. Olson's negative exponential decay model was used to calculate the litterbag decay constant, and all regression analyses were done by MS Excel (MS Excel 2000; Microsoft Cooperation, Redmond, WA, USA). Pearson's correlation coefficients were also calculated using MS Excel. The theoretical organic matter remaining on the forest floor (TOM) was calculated using the equation:

$$
\mathrm{TOM}=\mathrm{L} / \mathrm{k} .
$$

I compared $k, k_{1}, k_{2}$, and $k_{3}$ values to each other and also to the actual organic matter on the forest floor and TOM. The status of litter dynamics at each study site was determined through this comparison.

\section{RESULTS}

\section{Litterfall production}

Litterfall in Jirisan was collected only in August and November, and the ratios of autumn to annual litterfall in Deogyusan and Gyeryongsan were applied to the other months in order to obtain estimates of annual litterfall in the same or similar species stands. Annual litterfall in the litter traps (Table 2) ranged from $259 \mathrm{~g} / \mathrm{m}^{2}$ at Sk in Jirisan to $637 \mathrm{~g} / \mathrm{m}^{2}$ at Pd3 in Gyeryongsan $\left(434 \pm 91.6 \mathrm{~g} / \mathrm{m}^{2}\right)$. The amount of autumn litterfall was $39-49 \%$ of the annual litterfall in evergreen Pinus forests and greater than $60 \%$ of the annual litterfall in deciduous forests. Litterfalls at Cl1, Sk, Fm2, Ct1, Ct2, and Cl2 sites in Jirisan were collected only in August and November, and the autumn litterfall was $82-98 \%$ of the annual litterfall, which were higher than the others.

\section{Litterbag experiment}

Negative exponential decay models provided accurate descriptions of the litterbag data (Table 3). All regressions were significant $(P<0.05)$, and the fits were very good (mean, $r^{2}=0.918$; median, $r^{2}=0.926$; range, 0.761 to 0.991). Decay constants were very similar when the sites were close and the dominant plant species were the same, such as the case of the Ct1 and Ct2 sites. However, decay constants were very different when the sites were far apart from each other, such as the case of the Qs1, Qs2, and Qs3 sites, or when the dominant species were different, such as in the Qm2 and Pd1 sites. Decay constants were generally small in P. densiflora forests but those in the Qm3, Qm4, Qm5, Qs2, and Qs3 sites were even smaller than those of the Pinus forest.

Table 3. Negative exponential models and decay constants ( $k$; $1 / y)$ of

\begin{tabular}{|c|c|c|c|}
\hline Site & Decay equation & $\begin{array}{c}\text { Correlation } \\
\text { coefficient }\left(r^{2}\right)\end{array}$ & $\begin{array}{l}\text { Decay constant } \\
\text { (k) }\end{array}$ \\
\hline $\mathrm{Cl} 1$ & $\mathrm{y}=100 \mathrm{e}^{-0.3216 \mathrm{x}}$ & 0.960 & 0.322 \\
\hline $\mathrm{Cl} 2$ & $\mathrm{y}=100 \mathrm{e}^{-0.4306 \mathrm{x}}$ & 0.901 & 0.431 \\
\hline Ct1 & $\mathrm{y}=100 \mathrm{e}^{-0.4462 \mathrm{x}}$ & 0.773 & 0.446 \\
\hline $\mathrm{Ct} 2$ & $\mathrm{y}=100 \mathrm{e}^{-0.4882 \mathrm{x}}$ & 0.966 & 0.488 \\
\hline Fml & $\mathrm{y}=100 \mathrm{e}^{-0.3677 \mathrm{x}}$ & 0.975 & 0.368 \\
\hline Fm2 & $\mathrm{y}=100 \mathrm{e}^{-0.354 \mathrm{x}}$ & 0.909 & 0.354 \\
\hline Pd1 & $\mathrm{y}=100 \mathrm{e}^{-0.2879 \mathrm{x}}$ & 0.956 & 0.288 \\
\hline Pd2 & $\mathrm{y}=100 \mathrm{e}^{-0.2998 \mathrm{x}}$ & 0.932 & 0.300 \\
\hline $\mathrm{Pd} 3$ & $\mathrm{y}=100 \mathrm{e}^{-0.3085 \mathrm{x}}$ & 0.991 & 0.309 \\
\hline Qa & $\mathrm{y}=100 \mathrm{e}^{-0.3614 \mathrm{x}}$ & 0.917 & 0.361 \\
\hline Qm1 & $\mathrm{y}=100 \mathrm{e}^{-0.3315 \mathrm{x}}$ & 0.761 & 0.332 \\
\hline Qm2 & $\mathrm{y}=100 \mathrm{e}^{-0.4306 x}$ & 0.943 & 0.431 \\
\hline Qm3 & $\mathrm{y}=100 \mathrm{e}^{-0.2777 \mathrm{x}}$ & 0.904 & 0.278 \\
\hline Qm4 & $\mathrm{y}=100 \mathrm{e}^{-0.2914 \mathrm{x}}$ & 0.897 & 0.291 \\
\hline Qm5 & $\mathrm{y}=100 \mathrm{e}^{-0.2676 \mathrm{x}}$ & 0.974 & 0.268 \\
\hline Qs1 & $\mathrm{y}=100 \mathrm{e}^{-0.3834 \mathrm{x}}$ & 0.965 & 0.383 \\
\hline Qs2 & $\mathrm{y}=100 \mathrm{e}^{-0.2877 \mathrm{x}}$ & 0.803 & 0.288 \\
\hline Qs3 & $\mathrm{y}=100 \mathrm{e}^{-0.2479 \mathrm{x}}$ & 0.891 & 0.248 \\
\hline Qv1 & $y=100 e^{-0.352 x}$ & 0.982 & 0.352 \\
\hline Qv2 & $\mathrm{y}=100 \mathrm{e}^{-0.3336 \mathrm{x}}$ & 0.920 & 0.334 \\
\hline Sk & $\mathrm{y}=100 \mathrm{e}^{-0.4028 \mathrm{x}}$ & 0.968 & 0.403 \\
\hline
\end{tabular}
the study sites. 


\section{Litter on the forest floor and removal rates}

Ash-free mass ranged from $232 \mathrm{~g} / \mathrm{m}^{2}$ to $1,076 \mathrm{~g} / \mathrm{m}^{2}$ $\left(485 \pm 218.7 \mathrm{~g} / \mathrm{m}^{2}\right)$ for the $\mathrm{O}_{\mathrm{i}}$ horizon, and from $467 \mathrm{~g} / \mathrm{m}^{2}$ to $5,197 \mathrm{~g} / \mathrm{m}^{2}\left(1,881 \pm 1,152.0 \mathrm{~g} / \mathrm{m}^{2}\right)$ for the other $\left(\mathrm{O}_{\mathrm{e}}, \mathrm{O}_{\mathrm{a}}\right.$, and A) horizons (Table 4). The litter amount of the $\mathrm{O}_{\mathrm{i}}$ horizon was not significantly related with autumn litterfall (correlation coefficient $r=0.214$ ), indicating the movement of litter after it had fallen on the forest floor. Even though the ash-free mass of the $\mathrm{O}_{\mathrm{i}}$ horizon in the Pinus forest was small, those of the $\mathrm{O}_{e}, \mathrm{O}_{a}$, and A horizons were relatively large. Removal rates $k_{1}, k_{2}$, and $k_{3}$ were different at all sites. $\mathrm{k}_{1}$ was the largest; $\mathrm{k}_{2}$ was the smallest; and $\mathrm{k}_{3}$ was in between. The ranges of $k_{1}, k_{2}$, and $k_{3}$ were 0.176 $1.067 / \mathrm{y}(0.479 \pm 0.246 / \mathrm{y}), 0.049-0.717 / \mathrm{y}(0.282 \pm 0.173 / \mathrm{y})$, and $0.125-0.853 / \mathrm{y}(0.322 \pm 0.174 / \mathrm{y})$, respectively. The largest removal rates were observed in the Qs2 site at 1.067 $\left(\mathrm{k}_{1}\right) / \mathrm{y}, 0.717\left(\mathrm{k}_{2}\right) / \mathrm{y}$, and $0.853\left(\mathrm{k}_{3}\right) / \mathrm{y}$.

Table 4. Litter on the forest floor and mass balance-derived constants at the study sites

\begin{tabular}{|c|c|c|c|c|c|}
\hline \multirow{2}{*}{ Site } & \multicolumn{2}{|c|}{ Ash-free matter $\left(\mathrm{g} / \mathrm{m}^{2}\right)$} & \multicolumn{3}{|c|}{ Removal rates } \\
\hline & $\mathrm{O}_{\mathrm{i}}$ horizon & $\mathrm{O}_{\mathrm{e}}, \mathrm{O}_{\mathrm{a}}$ and $\mathrm{A}$ horizon & $\mathbf{k}_{1}$ & $\mathbf{k}_{2}$ & $\mathbf{k}_{3}$ \\
\hline $\mathrm{Cl} 1$ & 1,076 & 3,404 & 0.382 & 0.122 & 0.316 \\
\hline $\mathrm{Cl} 2$ & 747 & 2,413 & 0.324 & 0.144 & 0.310 \\
\hline Ct1 & 818 & 1,949 & 0.510 & 0.150 & 0.420 \\
\hline Ct2 & 568 & 2,501 & 0.231 & 0.143 & 0.227 \\
\hline Fm1 & 433 & 1,026 & 0.555 & 0.341 & 0.422 \\
\hline Fm2 & 580 & 2,487 & 0.252 & 0.107 & 0.233 \\
\hline Pd1 & 481 & 1,912 & 0.662 & 0.248 & 0.252 \\
\hline $\mathrm{Pd} 2$ & 232 & 1,848 & 0.258 & 0.256 & 0.125 \\
\hline Pd3 & 262 & 1,477 & 0.454 & 0.359 & 0.177 \\
\hline Qa & 336 & 792 & 0.675 & 0.487 & 0.424 \\
\hline Qm1 & 381 & 941 & 0.810 & 0.295 & 0.405 \\
\hline Qm2 & 497 & 1,444 & 0.401 & 0.285 & 0.344 \\
\hline Qm3 & 328 & 545 & 1.044 & 0.580 & 0.602 \\
\hline Qm4 & 432 & 2,950 & 0.245 & 0.127 & 0.146 \\
\hline Qm5 & 329 & 1,803 & 0.287 & 0.213 & 0.182 \\
\hline Qs1 & 406 & 1,243 & 0.463 & 0.307 & 0.327 \\
\hline Qs2 & 398 & 467 & 1.067 & 0.717 & 0.853 \\
\hline Qs3 & 312 & 713 & 0.702 & 0.510 & 0.438 \\
\hline Qv1 & 421 & 3,224 & 0.180 & 0.147 & 0.131 \\
\hline Qv2 & 305 & 1,159 & 0.371 & 0.330 & 0.264 \\
\hline Sk & 846 & 5,197 & 0.176 & 0.049 & 0.163 \\
\hline
\end{tabular}

$\mathrm{k}_{1}=\mathrm{L} / \mathrm{F}$, where $\mathrm{L}$ is the continuous litterfall mass; and $\mathrm{F}$ is the forest floor mass, $\mathrm{k}_{2}=-\ln \left(1-\mathrm{O}_{\mathrm{i}} / \mathrm{T}\right)$, where $\mathrm{T}=\mathrm{O}_{\mathrm{i}}+\mathrm{O}_{\mathrm{e}}+\mathrm{O}_{\mathrm{a}}+\mathrm{A}, \mathrm{k}_{3}=\mathrm{O}_{\mathrm{i}} /\left(\mathrm{O}_{\mathrm{e}}+\mathrm{O}_{\mathrm{a}}+\mathrm{A}\right)$.

\section{DISCUSSION}

It is known that litter production in deciduous temperature forests shows discrete annual production in the autumn (Olson 1963). However, the present study found that about $30 \%$ of the annual litter production occurs during the other seasons (also Sharma and Ambasht 1987, Kim and Chang 1989). The amount of litterfall is highly variable according to time and space, and this variability should be estimated for comparison (Sharma and Ambasht 1987, Knutson 1997). Long-term data sets need to be used for making this type of estimate. This is highlighted by the finding in which the standard deviation for our three-year data from Jirisan ranged from $16 \%$ to $53 \%$ of the mean, and those of the four-year data from Deogyusan and Gyeryongsan ranged from $3 \%$ to $38 \%$ of the mean.

When litter falls on the forest floor, it can move by wind or gravity. Movement depends on several factors, including the intensity and direction of wind, micro-topography, and density of shrubs (Lee and Cho 2000). Thus, the amount of litterfall produced in autumn as measured by the litter trap was different from the litter on the $\mathrm{O}_{\mathrm{i}}$ horizon of the forest floor in late autumn. Comparison of annual litter production should be done on litter trap-based data because the litter amount on the $\mathrm{O}_{\mathrm{i}}$ horizon differs according to micro-scale environments, and the litter amount on a forest floor at a specific site may not be representative of the whole forest ecosystem.

Hobbie et al. (2006) calculated $\mathrm{k}_{1}$ and $\mathrm{k}_{2}$ based on Olson's models. They used annual litter production and litter amount on the $\mathrm{O}$ horizons to calculate $\mathrm{k}_{1}$. To calculate $\mathrm{k}_{1}$ from mass balance estimates, the annual litter production data should be corrected with annual deposition data because the fallen litter does not remain fixed in any particular spot. This can be calculated with the equation $\mathrm{L}=\mathrm{O}_{\mathrm{i}} \times$ (annual literfall/autumn litterfall). If the annual litterfall data is converted to annual deposited amounts, the conversion factor should be determined by comparing the autumn litterfall and litter amount in the $\mathrm{O}_{\mathrm{i}}$ layer at the end of autumn. If the $\mathrm{O}_{\mathrm{i}}$ data from autumn is converted to the annual deposited amounts, the conversion factor should be determined by comparing the autumn litterfall and annual litterfall. Knutson (1997) calculated a conversion factor in the deciduous forests of northeast Iowa as the ratio of litter mass in the quadrat to the litterbox on the forest floor, and the mean of conversion factors from 1984 through 1993 was 1.5 (range, 1.32 to 1.75 ; $\mathrm{SD}, 0.150$ ). In the present study, the latter conversion factor was used, and the mean ratio of annual litterfall and autumn litterfall was 1.48 (range, 0.95 to 2.56; SD, 0.453). 
Hobbie et al. (2006) suggested that calcium is responsible for the difference between $\mathrm{k}$ and $\mathrm{k}_{1}$, and found that litter calcium was significantly related to $k_{2}$. However, this was not the case for this study because calcium in the soil was not correlated with the difference between $k$ and $k_{1}$ (Korea National Park Service 2002, 2004a, 2004b). The removal rates calculated by mass balance for many litter types were not always slower than the decay rates calculated from litterbags.

Even though decomposition in the litterbags was measured for only 2 or 3 years, the decay rate $(\mathrm{k})$ may not change with time because it was calculated using a regression equation of exponential decrease. Therefore, the decay rates may not have slowed with time as the relative amount of recalcitrant materials in the litter increased, which was suggested by Hobbie et al. (2006). If the litterbag decay constant $(\mathrm{k})$ and mass balance removal rates $\left(\mathrm{k}_{\mathrm{i}} ; \mathrm{k}_{1}, \mathrm{k}_{2}\right.$, and $\left.\mathrm{k}_{3}\right)$ are compared, $\mathrm{k}$ is unrelated to $\mathrm{k}_{\mathrm{i}}$, as was previously described by Hobbie et al. (2006). However, there were significant relationships among the removal rates themselves. Regression equations were $\mathrm{k}_{2}=0.5639 \mathrm{k}_{1}$ $+0.0119\left(r^{2}=0.7368, P<0.01\right) ; \mathrm{k}_{3}=0.5845 \mathrm{k}_{1}+0.0422$ $\left(r^{2}=0.7813, P<0.01\right) ;$ and $\mathrm{k}_{3}=0.8015 \mathrm{k}_{2}+0.0961\left(r^{2}=\right.$ $0.634, P<0.01)$. The $\mathrm{k}_{1}$ values were calculated from annual litterfall (L). Litter quality is different in each season, and in spring and summer, litter is more likely to be decomposed than in autumn and winter. The $\mathrm{k}_{1}$ might over-estimate the actual removal rate. The $\mathrm{k}_{2}$ values were calculated from the maximum accumulated biomass ( $\mathrm{T}$ ) and did not include disappeared biomass before; so, the actual removal rate might have been under-estimated. The $k_{3}$ values were in between $k_{1}$ and $k_{2}$, and were calculated through autumn litterfall and other remaining mass. Spring and summer litterfall is decomposed quicker than autumn litterfall because $\mathrm{N}$ and $\mathrm{P}$ contents are high and have little implication on accumulated mass. Other accumulated mass, except $\mathrm{O}_{\mathrm{i}}$, has much higher content of recalcitrant matter than $\mathrm{O}_{\mathrm{i}}$ mass. If there is a small amount of accumulated mass, this recalcitrant matter will not give much implication on the decomposition rate. Therefore, the $k_{3}$ values may be a good indicator of decomposition rate. A significant relationship among the removal rates themselves means that the comparison of $k$ with any one of $k_{1}, k_{2}$, or $k_{3}$ may have the same result. Here, it is recommend that $k_{3}$ is used because this variable can be easily determined based on the litter on the forest floor at the end of autumn or early winter and may accurately represents the actual removal rate.

\section{Assessment of the state of litter dynamics}

In this study, the decay rate and several types of removal rate were calculated. If litter dynamics on the forest floor were in a steady state, the decay rate $(\mathrm{k})$ and removal rate $\left(\mathrm{k}_{\mathrm{i}}\right)$ should be similar. However, they were similar at some sites and different at others. Some difference might have resulted from the differences in methods because a smaller fraction than mesh size was assigned to decomposed matter in litterbag method but the removed fraction at the site was only assigned to decomposed matter in mass balance estimates. Nevertheless, this difference is natural where the litter dynamics at the study site were not in equilibrium. Olson's equation $\mathrm{k}_{1}=\mathrm{L} / \mathrm{F}$ assumes that there is a steady state between input and output. Kim and Chang (1966) also assumed the steady state of litter input and output to calculate $\mathrm{k}_{3}$. Thereafter, many studies were done in South Korea (Chang and Ko 1982, Chang and Kim 1983, Chang and Chung 1986), and Chang et al. (1987) presented a decay map for South Korea that reflects latitude, altitude, and dominant species. However, $\mathrm{k}_{\text {and }} \mathrm{k}_{\mathrm{i}}$ were not similar at many sites in the present study. This means that litter input and output was not in equilibrium at those sites. As mentioned earlier, the litterfall amount on the $\mathrm{O}_{\mathrm{i}}$ horizon in autumn is not the same as the fallen amount in autumn at many sites because of micro-scale environmental differences, such as the location of the study site on a slope. This might be responsible for the difference between the decay rate and removal rate.

The use of a diagram showing the relationship between $\mathrm{k}$ and $\mathrm{k}_{\mathrm{i}}$ is suggested (Fig. 1). In the diagram, a diagonal line is drawn to indicate a 1:1 relationship, and two additional lines are included on either side of the diagonal line to represent one SD of the $\mathrm{k}_{3}$ values. One SD of the annual litter fall was less than $38 \%$ of the mean for 4 years, and $k_{3}$ closely represents the uncertainty of removal rates in the studied communities. If a site was between the two dotted lines, the litter dynamics on the forest floor would be defined operationally in equilibrium. However, this does not mean that they actually are. If a site was located in a faster removal zone, past long-term removal rates would be higher than the present decomposition rate. This might be true in old forests because these areas will tend to be inhabited by species resistant to decomposition with succession (Odum 1960, Kazakou et al. 2006, Cortez et al. 2007). Consistent species composition that has not changed remarkably might have resulted from lower input than output. If a site is located in a slower removal zone, the past long-term removal rate will be lower than the present decomposition rate. Litter removal in slower 

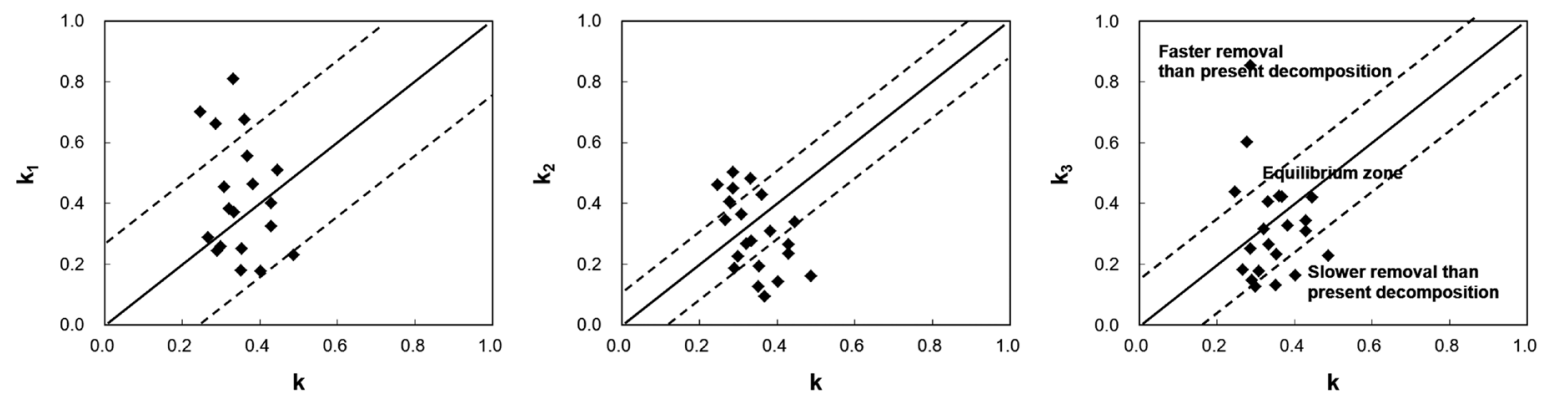

Fig. 1. Zoning the state of litter dynamics on the forest floor according to the litterbag-based decay rate, $k(1 / y)$, and mass balance removal rate, $k_{i}(1 / y)$. Dotted lines were drawn above and below the diagonal line to represent \pm 1 SD of the $k_{i}$ values. One SD of the $k_{1}, k_{2}$, and $k_{3}$ values in this study were 0.2636 , 0.1250 and 0.1743 , respectively.

removal zones will exceed the litter input, and a balance between removal and input will be achieved. From this analysis, the state of litter dynamics can be determined, and future changes can be predicted.

In the present study, all 21 sites contained well-conserved and stable ecosystems, and these should have been in equilibrium. However, only 14 sites were in equilibrium: four sites (Ct2, Pd2, Qv1, and Sk) were in a slower removal zone, and three sites (Qs2, Qs3, and Qm3) were in a faster removal zone. This was probably due to the location of the litter collection sites: four sites were in a valley, and three sites were on a ridge. Litter is blown by wind from ridges to valleys where it accumulates. This implies that litter should be collected at sites located in the middle of steady slopes to calculate the mass balance $\left(\mathrm{k}_{\mathrm{i}}\right)$. This study also suggests that the range of variation of $k_{3}$ in the equilibrium state is $\mathrm{k} \pm 0.1743$ in South Korea.

The other way to assess the state of litter dynamics on a forest floor is to compare the remaining mass on the forest floor with the theoretical mass remaining on the forest floor. Here, the theoretical mass remaining can be calculated based on Olson's exponential decay equation: $\mathrm{dm} / \mathrm{dt}=\mathrm{m}_{0} \mathrm{e}^{-\mathrm{kt}}$. If the mass input is in equilibrium, the mass remaining in the equilibrium state is an integral of this equation at $\mathrm{t}=\infty ; \mathrm{m}=\mathrm{m}_{0} / \mathrm{k}$, where $\mathrm{m}_{0}$ is the annual input on the forest floor. The $\mathrm{m}_{0}$ can be the actual input at the litter collection site and can be calculated from the conversion factors that were used to calculate $k_{1}$.

If the OAcc/TOM ratio at a site is larger than 1 , then accumulation would exceed decomposition. If the OAcc/ TOM ratio were smaller than 1 , the removal rate would be larger than the input rate. There are two possible mechanisms of higher accumulation than expected from the decay rate (k). One is the change in litter quality over time. The other is the larger input or production of litterfall than of decomposed or removal amounts. However, the

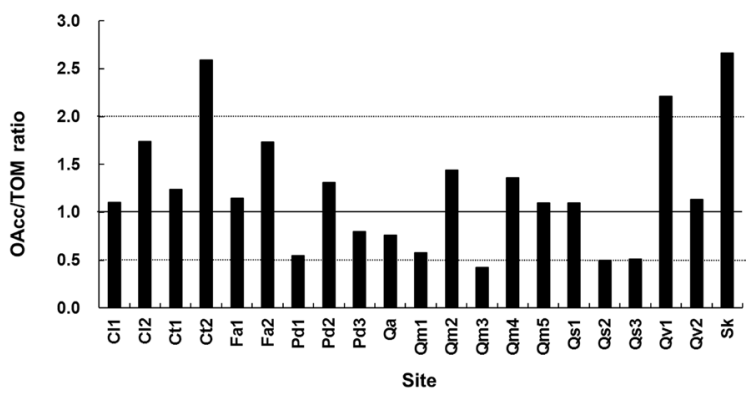

Fig. 2. Ratio of real and theoretical organic matter remaining on the forest floor (TOM) at each site. The theoretical organic matter remaining was calculated assuming that there was a steady input of organic matter and a constant decay rate (k). OAcc, organic accumulation.

data in this study indicates that there should be a reasonable range of deviation of the OAcc/TOM ratio because of the annual variation in litterfall. The OAcc/TOM ratio in the equilibrium state based on the $\mathrm{k}_{3}-\mathrm{k}$ diagram ranged from 0.4 to 2.7 (Fig. 2). The Ct2 and Sk sites were in a hollow area and have highest the OAcc/TOM ratios.

Even though decomposition is driven by the environment on both regional and micro-site scales, the substrate quality of litter, the composition of the decomposer community (Parton et al. 1987, Aerts 1996, Cornelissen 1999), and the magnitude of species-driven differences may be much larger than previously thought and greater than climate-driven variations (Cornwell et al. 2008). Litter quality changes with succession (Cornwell et al. 2008). In general, fast-growing, poorly-defended species of angiosperms produce litter with a high decomposability; whereas, slower-growing, better-defended species produce poor-quality litter with low decomposition rates (Cornelissen et al. 1999). Among the sites in the present study, Pd1, Pd2, and Pd3 were dominated by the gymnosperm $P$. densiflora, while other sites were dominated by angiosperms. Decomposition of gymnosperms is gener- 
ally slower than that of angiosperms (Chang et al. 1987, Cornwell et al. 2008). However, the OAcc/TOM ratios of Pd1 and Pd3 were lower than 1, meaning that removal was faster than input. The OAcc/TOM ratios of some sites dominated by angiosperms were larger than 1 . Therefore, litter quality changes with succession do not affect the OAcc/TOM in this study.

In this study, the range of decay rates (k) among the sites was small, even though the sites were dominated by different species. However, the range of removal rates was relatively large. This does not reflect the difference in decomposition rates but rather differences in input and output on a small scale. The range of ash-free litter on the $\mathrm{O}_{\mathrm{i}}$ horizon was large, but the input amount was not solely responsible for the OAcc/TOM ratio. Microenvironmental factors such as rock coverage, soil texture, moisture content, and topography might be responsible for the input/ output difference.

In conclusion, the present study shows that litterfall dynamics on the forest floor can be understood through the comparison of $k$ and $k_{i}$ and the OAcc/TOM ratio. However, the mechanism of litter dynamics cannot be understood only through conventional experiments, and, therefore, further research on microenvironmental factors that affect the litter output/input in different ecosystems is required.

\section{ACKNOWLEDGMENTS}

The author would like to thank Eun Jeong Ju, Yang Woo Lee, Gi Jin Kwon, Bo Ah Lee, Heungtae Kim, Jong Min Nam, Jihyun Yoon, Sorin Kim, Seunghye Jeon, Yong Chul Lee, Mun Gi Hong, Heonyoung Lee, and Sungje Jeon for assistance with the fieldwork, and Professor E. Rejmankova (UC Davis) for valuable comments in improving the manuscript. This study was supported by the Korea National Park Service as a "Natural Resource Monitoring Program".

\section{LITERATURE CITED}

Aerts R. 1996. Nutrient resorption from senescing leaves of perennials: are there general patterns? J Ecol 84: 597608.

Barbour MG, Burk JH, Pitts WD, Gilliam FS, Schwartz MW. 1999. Terrestrial Plant Ecology. 3rd ed. Addison Wesley Longman, New York.

Birk EM, Simpson RW. 1980. Steady state and the continuous input model of litter accumulation and decomposition in Australian Eucalypt forest. Ecology 61: 481-485.

Brady NC, Weil RR. 2008. The Nature and Properties of Soils. 14th ed. Pearson, Upper Saddle River, NJ.

Chang NK, Chung MA. 1986. A study on the production and decomposition of litters along altitude of Mt. Dŏkyoo. Korean J Ecol 9: 185-192. (in Korean)

Chang NK, Kim IJ. 1983. A study of the matter production and decomposition of Quercus serrata and Carpinus laxiflora forests at Piagol in Mt. Jiri. Korean J Ecol 6: 198207. (in Korean)

Chang NK, Ko MH. 1982. Turnover rates of mineral nutrients of litters under Pinus koraiensis and Pinus rigida forests. Korean J Ecol 5: 28-33. (in Korean)

Chang NK, Lee SK, Lee BS, Kim HB. 1987. The decay map and turnover cycles of litters in Korea. Korean J Ecol 10: 183193. (in Korean)

Coleman DC, Crossley DA, Hendrix PF Jr. 2004. Fundamentals of Soil Ecology. 2nd ed. Elsvier, Sandiego, CA.

Cornelissen JHC, Pérez-Harguindeguy N, Díaz S, Grime JP, Marzano B, Cabido M, Vendramini F, Cerabolini B. 1999. Leaf structure and defense control litter decomposition rate across species and life forms in regional floras of two continents. New Phytol 143: 191-200.

Cornwell WK, Cornelissen JHC, Amatangelo K, Dorrepaal E, Eviner VT, Godoy O, Hobbie SE, Hoorens B, Kurokawa H, Pérez-Harguindeguy N, Quested HM, Santiago LS, Wardle DA, Wright IJ, Aerts R, Allison SD, van Bodegom P, Brovkin V, Chatain A, Callaghan TV, Díaz S, Garnier E, Gurvich DE, Kazakou E, Klein JA, Read J, Reich PB, Soudzilovskaia NA, Vaieretti MV, Westoby M. 2008. Plant species traits are the predominant control on litter decomposition rates within biomes worldwide. Ecol Lett 11: 1065-1071.

Cortez J, Garnier E, Pérez-Harguindeguy N, Debussche M, Gillon D. 2007. Plant traits, litter quality and decomposition in a Mediterranean old-field succession. Plant Soil 296: 19-34.

Edmonds RL. 1979. Decomposition and nutrient release in Douglas-fir needle litter in relation to stand development. Can J For Res 9: 132-140.

Edwards NT. 1975. Effects of temperature and moisture on carbon dioxide evolution in a mixed deciduous forest floor. Soil Sci Soc Am J 39: 361-365.

Ewel JJ. 1976. Litter fall and leaf decomposition in a tropical forest succession in eastern Guatemala. J Ecol 64: 293308.

Gallardo A, Merino J. 1993. Leaf decomposition in two Mediterranean ecosystems of southeast Spain: influence of substrate quality. Ecology 74: 152-161. 
Gessner MO, Chauvet E. 2002. A case for using litter breakdown to assess functional stream integrity. Ecol Appl 12: 498-510.

Gosz JR, Likens GE, Bormann FH. 1973. Nutrient release from decomposing leaf and branch litter in the Hubbard Brook Forest, New Hampshire. Ecol Monogr 43: 173-191.

Hobbie SE, Reich PB, Oleksyn J, Ogdahl M, Zytkowiak R, Hale C, Karolewski P. 2006. Tree species effects on decomposition and forest floor dynamics in a common garden. Ecology 87: 2288-2297.

Insam H. 1990. Are the soil microbial biomass and basal respiration governed by the climatic regime? Soil Biol Biochem 22: 525-532.

Johansson MB. 1994. Decomposition rates of Scots pine needle litter related to site properties, litter quality, and climate. Can J For Res 24: 1771-1781.

Johansson MB, Berg B, Meentemeyer V. 1995. Litter massloss rates in late stages of decomposition in a climatic transect of pine forests: long-term decomposition in a Scots pine forest. IX. Can J Bot 73: 1509-1521.

Kazakou E, Vile D, Shipley B, Gallet C, Garnier E. 2006. Covariations in litter decomposition, leaf traits and plant growth in species from a Mediterranean old-field succession. Funct Ecol 20: 21-30.

Kim CM, Chang NK. 1966. The decomposition rate of pine and oak litters affecting the amount of mineral nutrients of forest soil in Korea. Seoul Natl Univ J 17: 83-92. (in Korean)

Kim JG, Chang NK. 1989. Litter production and decomposition in the Pinus rigida plantation in Mt. Kwan-ak. Korean J Ecol 12: 9-20. (in Korean)

Knoepp JD, Coleman DC, Crossley DA Jr, Clark JS. 2000. Biological indices of soil quality: an ecosystem case study of their use. For Ecol Manage 138: 357-368.

Knutson RM. 1997. An 18-year study of litterfall and litter decomposition in a northeast Iowa deciduous forest. Am Midl Nat 138: 77-83.

Korea National Park Service. 2002. Natural Resources Monitoring at Jirisan National Park. Korea National Park Service, Seoul. (in Korean)

Korea National Park Service. 2004a. Natural Resources Monitoring at Gyeryongsan National Park. Korea National Park Service, Seoul. (in Korean)

Korea National Park Service. 2004b. Natural Resources Monitoring at Deogyusan National Park. Korea National Park Service, Seoul. (in Korean)

Laskowski R, Niklinska M, Maryanski M. 1995. The dynamics of chemical elements in forest litter. Ecology 76: 13931406.
Lee KS, Cho DS. 2000. Relationships between the spatial distribution of vegetation and microenvironment in a temperate hardwood forest in Mt. Jumbong biosphere reserve area, Korea. Korean J Ecol 23: 241-253. (in Korean)

Meentemeyer V. 1978. Macroclimate and lignin control of litter decomposition rates. Ecology 59: 465-472.

Melillo JM, Aber JD, Muratore JF. 1982. Nitrogen and lignin control of hardwood leaf litter decomposition dynamics. Ecology 63: 621-626.

Odum EP. 1960. Organic production and turnover in old field succession. Ecology 41: 34-49.

Odum EP. 1985. Trends expected in stressed ecosystems. BioScience 35: 419-422.

Olson JS. 1963. Energy storage and the balance of producers and decomposers in ecological systems. Ecology 44: 322-331.

Parton WJ, Schimel DS, Cole CV, Ojima DS. 1987. Analysis of factors controlling soil organic matter levels in the Great Plains grasslands. Soil Sci Soc Am J 51: 1173-1179.

Rapport DJ, Regier HA, Hutchinson TC. 1985. Ecosystem behavior under stress. Am Nat 125: 617-640.

Rustad LE. 1994. Element dynamics along a decay continuum in a red spruce ecosystem in Maine, USA. Ecology 75: 867-879.

Schaeffer DJ, Herricks EE, Kerster HW. 1988. Ecosystem health: I. measuring ecosystem health. Environ Manage 12: 445-455.

Sharma E, Ambasht RS. 1987. Litterfall, decomposition and nutrient release in an age sequence of Alnus nepalensis plantation stands in the Eastern Himalaya. J Ecol 75: 997-1010.

Shin CH, Won HY, Mun HT. 2011. Litter production and nutrient input via litterfall in Quercus mongolica forest at Mt. Worak National Park. J Ecol Field Biol 34: 107-113.

Swift MJ, Heal OW, Anderson JM. 1979. Decomposition in Terrestrial Ecosystems. University of California Press, Berkley, CA.

Taylor BR, Prescott CE, Parsons WJF, Parkinson D. 1991. Substrate control of litter decomposition in four Rocky Mountain coniferous forests. Can J Bot 69: 2242-2250.

Turner J, Long JN. 1975. Accumulation of organic matter in a series of douglas-fir stands. Can J For Res 5: 681-690.

van Voris P, O’Neill RV, Emanuel WR, Shugart HH Jr. 1980. Functional complexity and ecosystem stability. Ecology 61: 1352-1360.

Vitousek PM. 1994. Beyond global warming: ecology and global change. Ecology 75: 1861-1876.

Yavitt JB, Fahey TJ. 1986. Litter decay and leaching from the forest floor in Pinus contorta (Lodgepole pine) ecosystems. J Ecol 74: 525-545. 